\title{
Multihost saprobes are facultative pathogens of bullfrog Lithobates catesbeianus eggs
}

\author{
Gregory R. Ruthig ${ }^{1,3, *}$, Katie N. Provost-Javier ${ }^{1,2,4}$ \\ ${ }^{1}$ Mountain Lake Biological Station, University of Virginia, Charlottesville, Virginia 22904, USA \\ ${ }^{2}$ The College of William and Mary, Williamsburg, Virginia 23187, USA \\ ${ }^{3}$ Present address: Department of Biology, North Central College, Naperville, Illinois 60540, USA \\ ${ }^{4}$ Present address: The W. Harry Feinstone Department of Molecular Microbiology and Immunology, \\ Bloomberg School of Public Health, Johns Hopkins University, Baltimore, Maryland 21205, USA
}

\begin{abstract}
Pathogens that infect more than one host species create complex linkages in ecological communities. We tested whether saprobes that grow on multiple host species in aquatic systems can be facultative pathogens of amphibian eggs. We isolated oomycetes from dead arthropods, vertebrates, plant leaves, and frog eggs that coexisted in a small pond. Analysis of internal transcribed spacer regions of rDNA (ITS1-5.8S-ITS2) indicated that several of the strains colonized more than one substrate, including bullfrog Lithobates catesbeianus eggs. In a controlled experiment, isolates from 7 different host species were pathogenic to L. catesbeianus eggs. These results demonstrate that dead organisms can serve as reservoirs for facultative pathogens.
\end{abstract}

KEY WORDS: Oomycetes - Water molds ' Multihost pathogen ' Amphibian disease · Opportunistic pathogen · Internal transcribed spacer

\section{INTRODUCTION}

Pathogens are increasingly recognized as important members of ecological communities (Bradley et al. 2008, Kuris et al. 2008). In particular, pathogens that infect multiple hosts can increase linkages between members of communities (Huxham et al. 1995, Lafferty et al. 2006). Multihost pathogens can also maintain a presence in a community, even when one or more of their host populations decline, by infecting alternative hosts (Fenton \& Pedersen 2005). Many pathogens, bacteria and fungi in particular, can persist as saprobes, but act facultatively as pathogens when conditions are right (Anderson \& May 1981). Facultative pathogens can act as opportunistic pathogens (e.g. Anaissie 1992) or secondary pathogens (e.g. Daniel et al. 1999) that infect hosts only when the host is weakened in some way. They are increasingly becoming important to the medical field with the rise of immunocompromised patients (Anaissie 1992, Daniel et al. 1999). In most cases facultative pathogens have only been considered in a single host (e.g. Anderson \& May 1981). The ability of generalist saprobes to become facultative pathogens has not been considered in as much detail, particularly in an ecological context (Godfray et al. 1999).

The ability of facultative pathogens to persist or reproduce outside of the disease cycle reduces their reliance on their hosts (Godfray et al. 1999). Pathogen pollution, the spread of emerging infectious diseases by humans (Daszak et al. 2000), becomes more likely when infective spores persist outside of their hosts. Pathogen pollution contributes to the emergence of new infectious diseases, such as the amphibian chytrid fungus Batrachochytrium dendrobatidis, which has been implicated in global amphibian declines and extinctions (Daszak et al. 2003). 
Facultative pathogens that colonize more than one host species are particularly difficult for public health and wildlife officials to control. For example, the Australian fungal pathogen Cryptococcus gatti, which causes severe pulmonary and nervous system infections in humans and other animals, has successfully spread through Canadian British Columbia by its ability to infect multiple host species and by being accidentally moved by humans (Kidd et al. 2004, 2007). Despite its pathogenic effects on animals, C. gatti most commonly colonizes trees and dead wood and can also persist on the soles of shoes and vehicle tires for months (Kidd et al. 2007).

One group of organisms that has been well documented as both pathogens (Phillips et al. 2008) and saprobes (Johnson et al. 2002) is water molds of the class Oomycota, family Saprolegniaceae. Species of oomycetes are pathogens of plants (Papavizas \& Ayers 1964), algae (Gachon et al. 2009), vertebrates (Willoughby 1994) and invertebrates (Martin 1981, Oidtmann et al. 2004). Water molds have been found on eggs of amphibians around the world (e.g. Blaustein et al. 1994, Williamson \& Bull 1994, FernándezBenéitez et al. 2008, Ruthig 2008). However in some cases, water molds growing on amphibian eggs in the field were not pathogenic to eggs in controlled experiments. To date, eggs of green frogs Lithobates clamitans (Karraker \& Ruthig 2009) and spotted salamanders Ambystoma maculatum (Gomez-Mestre et al. 2006, Karraker \& Ruthig 2009) have been found to be resistant to infection when exposed to oomycete strains that were isolated from egg masses in the field. In cases where water molds did not infect their hosts in experiments, the oomycetes have been proposed to be acting saprobically in the field (Karraker \& Ruthig 2009).

Recent advances in molecular identification of water molds using the internal transcribed spacer (ITS) region (White et al. 1990) have uncovered a diversity of water molds within aquatic communities (Petrisko et al. 2008). Within a pond, different amphibian species can be infected by different water mold species (Ruthig 2009) and single infected amphibian eggs can be infected by multiple species of water molds (Ault et al. 2012).

Water molds spread in nature by 2 modes: (1) zoospores released by zoosporangia and (2) hyphal growth. Zoospore release often consists of 2 stages, primary zoospores and secondary zoospores. Primary zoospores encyst not far from the parent colony where they germinate and release secondary zoospores. Secondary zoospores play a large part in the spread of water molds. They are chemotaxic (Picker- ing \& Willoughby 1982) and able to locate a proper substrate for germination and growth (Beakes et al. 1995). Zoospores are the main source of transmission between hosts while hyphal growth spreads infection within a host or among adjacent hosts (K. N. Provost \& G. R. Ruthig unpubl. data).

Water mold infections on bullfrog Lithobates catesbeianus egg masses are common in Riopel Pond at the Mountain Lake Biological Station (MLBS) in Virginia. In 2003 and 2004, over $10 \%$ of the eggs died with signs of water mold infections with some egg masses having over $90 \%$ mortality (Ruthig 2006). In a controlled experiment water molds had a strongly negative effect on the survivorship of L. catesbeianus eggs (Ruthig 2009). Transmission of water mold diseases on $L$. catesbeianus eggs differs from traditional epidemiological models in 3 ways: (1) a single pathogen strain may infect multiple host species, (2) water molds can reproduce as pathogens or as saprobes, and (3) transmission of water molds does not occur until after their hosts are dead (Ruthig 2009). To better understand the community of water molds that infect L. catesbeianus eggs, we isolated and identified water molds from multiple hosts that shared a pond with a population of L. catesbeianus. We experimentally determined the ability of water mold isolates to infect and kill eggs.

\section{MATERIALS AND METHODS}

\section{Study site and sample collection}

We collected all water mold isolates and Lithobates catesbeianus eggs from Riopel Pond at the MLBS in Giles County, Virginia, USA (37²2' 28.52" N, $\left.80^{\circ} 31^{\prime} 19.80^{\prime \prime} \mathrm{W}\right)$. All isolates were collected in late May, June, and July of 2002, 2003 and 2004 during times when L. catesbeianus eggs were present in the pond. We collected water mold isolates from $11 \mathrm{~L}$. Catesbeianus eggs, 11 dead animals, and 1 decaying white oak leaf Quercus alba (Table 1). Oomycetes were isolated by placing a dead organism on a petri dish with cornmeal agar and cutting the leading tip of hyphae that grew from the organism after 24 to 48 h (Ruthig 2008).

\section{Identification of isolates}

To identify isolates, we sequenced the internal transcribed spacer (ITS1-5.8S-ITS2) regions of the ribosomal DNA (White et al. 1990). ITS sequences 
Table 1. Isolate names, GenBank numbers, year isolated and sources for oomycetes in this study. Isolates collected in 2003 and 2004 are from the Mountain Lake Biological Station (MLBS). Isolates in pathogenicity experiment in bold. Strains (A, B, or C) indicate isolates with identical internal transcribed spacer (ITS) sequences. na: not applicable

\begin{tabular}{|c|c|c|c|}
\hline Sample & Accession no. & Year & Source \\
\hline \multicolumn{4}{|l|}{ Strain A } \\
\hline Lithobates catesbeianus egg ${ }^{\mathrm{a}}$ & GU014271 & 2003 & Lithobates catesbeianus egg \\
\hline EM 31 End & GU014264 & 2004 & Lithobates catesbeianus egg \\
\hline EM 7 & GU014266 & 2004 & Lithobates catesbeianus egg \\
\hline EM 31 B End & GU014264 & 2004 & Lithobates catesbeianus egg \\
\hline EM $47 \mathrm{~A}$ & GU014274 & 2004 & Lithobates catesbeianus egg \\
\hline EM 23 & GU014272 & 2004 & Lithobates catesbeianus egg \\
\hline EM 26 B & GU014265 & 2004 & Lithobates catesbeianus egg \\
\hline EM $32 \mathrm{C}$ & GU014273 & 2004 & Lithobates catesbeianus egg \\
\hline 02 R. cat. egg & GU014276 & 2002 & Lithobates catesbeianus egg \\
\hline EM 25 & GU014267 & 2004 & Lithobates catesbeianus egg \\
\hline Cord $1 \mathrm{~A}$ & GU014262 & 2004 & Dragonfly larva (Family Corduliidae) \\
\hline Libellula pulchella & GU014268 & 2003 & Libellula pulchella larva \\
\hline Moth 2 & GU014275 & 2004 & Moth adult \\
\hline Moth adult 3 & GU014270 & 2004 & Moth adult \\
\hline Pseudacris crucifer tadpole B2 & GU014269 & 2004 & Pseudacris crucifer tadpole \\
\hline Scarab adult & GU014261 & 2004 & Scarab beetle adult (Family Scarabaeidae) \\
\hline Lithobates clamitans egg & EU480454 & na & Lithobates clamitans egg \\
\hline Lithobates sphenocephalus 14 & EU348371 & na & Lithobates sphenocephalus egg \\
\hline Lithobates sphenocephalus 26 & EU348372 & na & Lithobates sphenocephalus egg \\
\hline \multicolumn{4}{|l|}{ Strain B } \\
\hline EM 32 A & GU014278 & 2004 & Lithobates catesbeianus egg \\
\hline Pseudacris crucifer adult & GU014279 & 2003 & Pseudacris crucifer adult \\
\hline Notopthalmus viridescens & GU014277 & 2003 & Notopthalmus viridescens adult \\
\hline \multicolumn{4}{|l|}{ Strain C } \\
\hline AESB & GU014282 & 2004 & Dragonfly larva (Family Aeshnidae) \\
\hline Pseudacris crucifer egg & GU014283 & 2004 & Pseudacris crucifer egg \\
\hline \multicolumn{4}{|l|}{ Unique sequences } \\
\hline Saprolegnia longicaulis & AY270032 & na & GenBank \\
\hline Saprolegnia anamolies & DQ322632 & na & GenBank \\
\hline Saprolegnia bulbosa & AY267011 & na & GenBank \\
\hline Saprolegnia ferax & EU240105 & na & GenBank \\
\hline Saprolegnia oliviae & AY270031 & na & GenBank \\
\hline Saprolegnia parasitica & EU750732 & na & GenBank \\
\hline Saprolegnia salmonis & AY647193 & na & GenBank \\
\hline Saprolegnia hypogyna & AY647188 & na & GenBank \\
\hline Saprolegnia diclina & AY455775 & na & GenBank \\
\hline Quercus alba & GU014280 & 2003 & Quercus alba leaf \\
\hline NVA3 & GU014281 & 2004 & Notopthalmus viridescens adult \\
\hline Leptolegnia 1 & AM228851 & na & GenBank \\
\hline Leptolegnia 2 & AY310502 & na & GenBank \\
\hline Leptolegnia 3 & EU240098 & na & GenBank \\
\hline Aspergillus tubingensis & GQ169025 & na & GenBank \\
\hline Pythium parvum & AB362332 & na & GenBank \\
\hline Pythium takayamanum & AB362163 & na & GenBank \\
\hline Pythium erinaceum & AB362165 & na & GenBank \\
\hline Phytopthora botryosa & AF266784 & na & GenBank \\
\hline Phytopthora colocasiae & GQ202150 & na & GenBank \\
\hline Aphanomyces stellatus & AM947029 & na & GenBank \\
\hline Aphanomyces frigidophilus & FM992370 & na & GenBank \\
\hline Aphanomyces astaci & AM947027 & na & GenBank \\
\hline Saprolegnia semihypogyna & AY647194 & na & GenBank \\
\hline Achlya racemosa & AF218158 & na & GenBank \\
\hline Achlya colorata & AF218159 & na & GenBank \\
\hline Achlya papillosa & AF218161 & na & GenBank \\
\hline Achlya aquatica & AF218150 & na & GenBank \\
\hline Achlya primoachlya & EU849168 & na & GenBank \\
\hline Achlya americana & AF218145 & na & GenBank \\
\hline Achlya intricata & AF218148 & na & GenBank \\
\hline Achlya ambisexualis & AF218147 & na & GenBank \\
\hline Achlya heterosexualis & AF218165 & na & GenBank \\
\hline
\end{tabular}


are commonly used as characters for taxonomy of Saprolegniaceae (Leclerc et al. 2000, Hulvey et al. 2007, Petrisko et al. 2008) and have been sequenced in many other types of organisms (Vilgalys \& Sun 1994). After amplification by PCR, the ITS region (primers ITS-1, 5'-TCC GTA GGT GAA CCT GCG G-3'; and ITS-4, 5'-TCC TCC GCT TAT TGA TAT GC-3') of the water mold ribosomal DNA was sequenced on an Applied Biosystems 3730XL 96-capillary sequencer at the University of Chicago Cancer Research Center.

Using Mega 4.0 (Tamura et al. 2007), we aligned the ITS region of isolates collected from MLBS with homologous ITS regions from reference samples acquired from Genbank, including the genera Achlya, Leptolegnia, Saprolegnia (see Petrisko et al. 2008), Aphanomyces, Pythium, and an ITS sequence from one true fungi to serve as an out-group. To determine the identity of isolates we collected, we performed a distance analysis of our isolates and reference samples using the Jukes-Cantor model of Mega 4.0. We performed a bootstrap analysis of the neighbor-joining tree with 10000 replicates.

\section{Infection experiment}

To determine if water molds isolated from different host species were pathogenic to Lithobates catesbeianus eggs, we performed an infection experiment. We grew each of the 6 isolates from 2003 (Table 1) and, as a positive control, a known L. catesbeianus egg pathogen isolate collected in 2002 (Ruthig 2009) to confluence on cornmeal agar plates. Cultures for each isolate and a sterile cornmeal agar plate, our negative control, were divided into $1 \mathrm{~cm}^{3}$ pieces. Pieces were placed individually in cups of $60 \mathrm{ml}$ of boiled pond water and left for $3 \mathrm{~d}$ to allow for zoospore release. We then removed agar from the cups to reduce the chance that eggs would be infected via hyphae.

We collected Lithobates catesbeianus eggs from a single clutch laid in Riopel Pond. Because we performed nightly surveys of the pond, we knew that the eggs had been laid within the previous $10 \mathrm{~h}$. We placed one egg in each cup and monitored for mortality and hatching daily until all surviving eggs hatched. This was done in replicates of 100 for each of 8 treatments. We arranged treatments randomly in a $20^{\circ} \mathrm{C}$ temperature controlled room with a $12 \mathrm{~h}$ light/ dark cycle. We compared the number of infected eggs among the 8 treatments with a chi-square test. We also tested whether individual strains differed from the sterile control and the 'L. catesbeianus egg' strain in separate pairwise comparisons where alpha was adjusted using the Dunn-Šidák method.

\section{RESULTS}

\section{Field isolates}

We sequenced and aligned $573 \mathrm{bp}$ fragments of the ITS regions from 23 of the 24 oomycete isolates that we collected in 2003 and 2004. Isolates were considered the same 'strain' if the sequenced ITS region was identical. If a strain had a small $(<5)$ number of base pairs that were unreadable but was otherwise identical to other strains, it was considered to have an identical sequence. The ITS region can vary by 1 to $2 \%$ within species (Harvey \& Goff 2006), and we believe that our isolates equate to a single species. Sixteen isolates collected at MLBS were identical (Strain A; Table 1, Fig. 1). Three other isolates were identical to one another (Strain B). Two additional sequences clustered under a third group (Strain C); sequences of the remaining 2 isolates were unique.

The phylogeny identified the genera of our field isolates (Fig. 1). Strain A grouped with species of Leptolegnia and Strain B grouped with species of Achlya. Isolates in Strain C are most likely Saprolegnia. The 'Quercus alba' strain was just basal to the genus Pythium and one of our strains collected from an adult Notopthalmus viridescens (NVA 3 in Table 1) was just basal to Aphanomyces.

\section{Infection experiment}

Isolates differed in their ability to infect Lithobates catesbeianus eggs $\left(\chi^{2}=195.57\right.$, df $\left.=7, p<0.0001\right)$ (Fig. 2). All eggs in treatments exposed to water molds had higher mortality than the controls $(\mathrm{p}=$ $0.007)$. Four of 6 isolates differed significantly from the positive control $(\mathrm{p}=0.009)$. Isolates from the Pseudacris crucifer eggs (Strain C) and Quercus alba (unique) were less pathogenic, while the isolates from both Notopthalmus viridescens and P. crucifer adults (both Strain B) were more pathogenic than the bullfrog egg isolate. Infection levels from inoculation with 'Libellula pulchella' (Strain A) and 'Lithobates catesbeianus tadpole' did not differ significantly from those of the L. catesbeianus egg isolate. The number of eggs infected by the L. catesbeianus tadpole isolate was the same as the number infected by the 


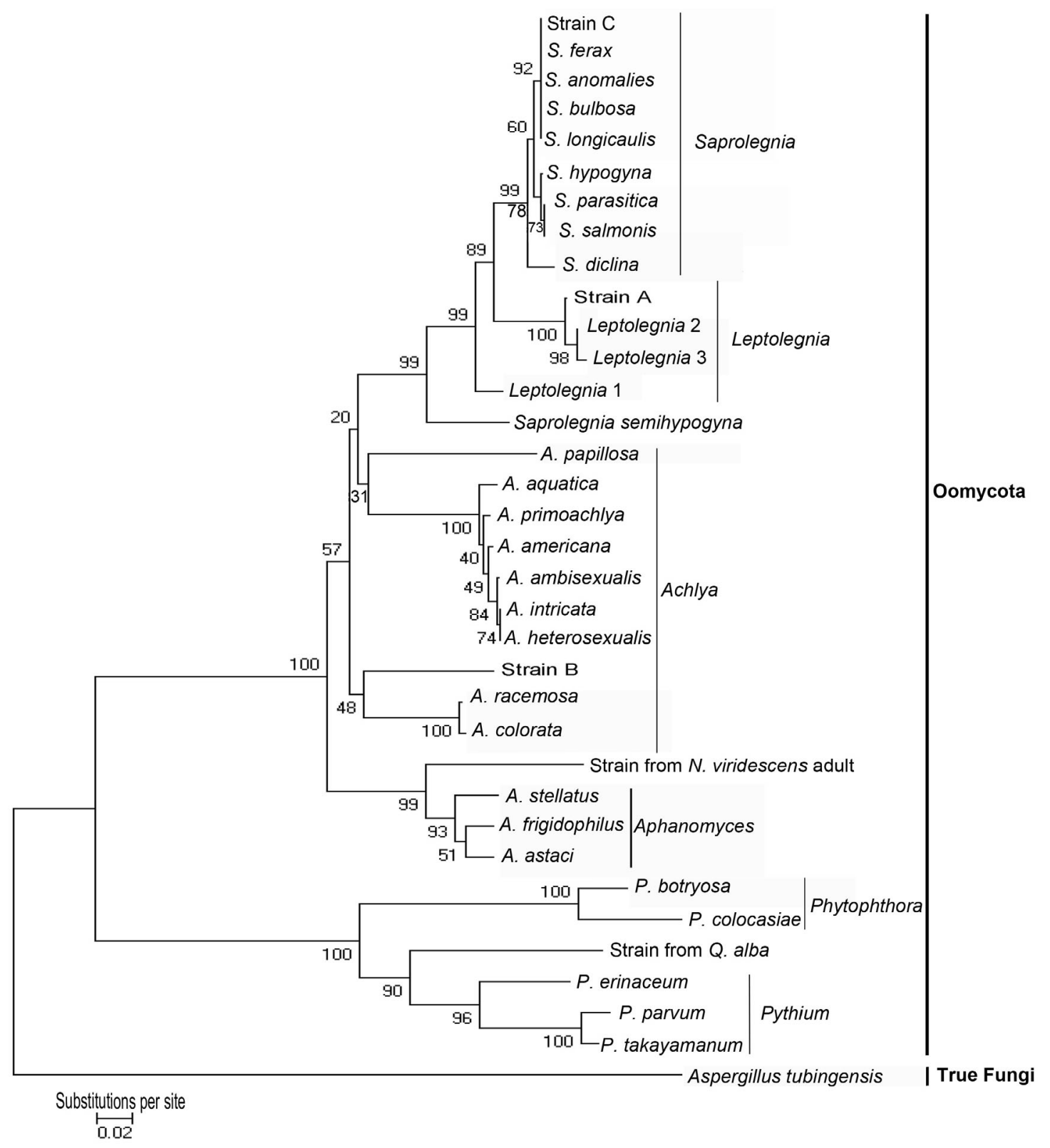

Fig. 1. Jukes-Cantor neighbor-joining distance tree for oomycete isolates collected from Riopel Pond at Mountain Lake Biological Station (MLBS) and reference oomycete and fungi samples obtained from GenBank. Strains A, B, and C each consisted of several isolates whose internal transcribed spacer (ITS) sequences were identical to each other. See Table 1 for sample descriptions

L. catesbeianus egg isolate; unfortunately, we were unable to obtain an ITS sequence for this isolate.

Several isolates that were pathogenic to Lithobates catesbeianus eggs were collected on other species in the field (Table 1). Strain A, which included 'L. catesbeianus egg' and 'Libellula pulchella' isolates, was found predominantly on L. catesbeianus eggs in the field (10 of 11 isolates), but also on insects (2 moths and a scarab beetle) and a Pseudacris crucifer tad- pole. The ITS sequences of this strain were identical to those of a pathogenic water mold isolated from Lithobates sphenocephalus in South Carolina (Ruthig 2008), suggesting that Strain A is not unique to our study's site or to L. catesbeianus eggs. Strain B, including 'Notopthalmus viridescens adult' and 'Pseudacris crucifer adult' isolates, was also found on $L$. catesbeianus eggs in the field. Lastly, the 'P. crucifer egg' isolate (Strain C) was found on one other 


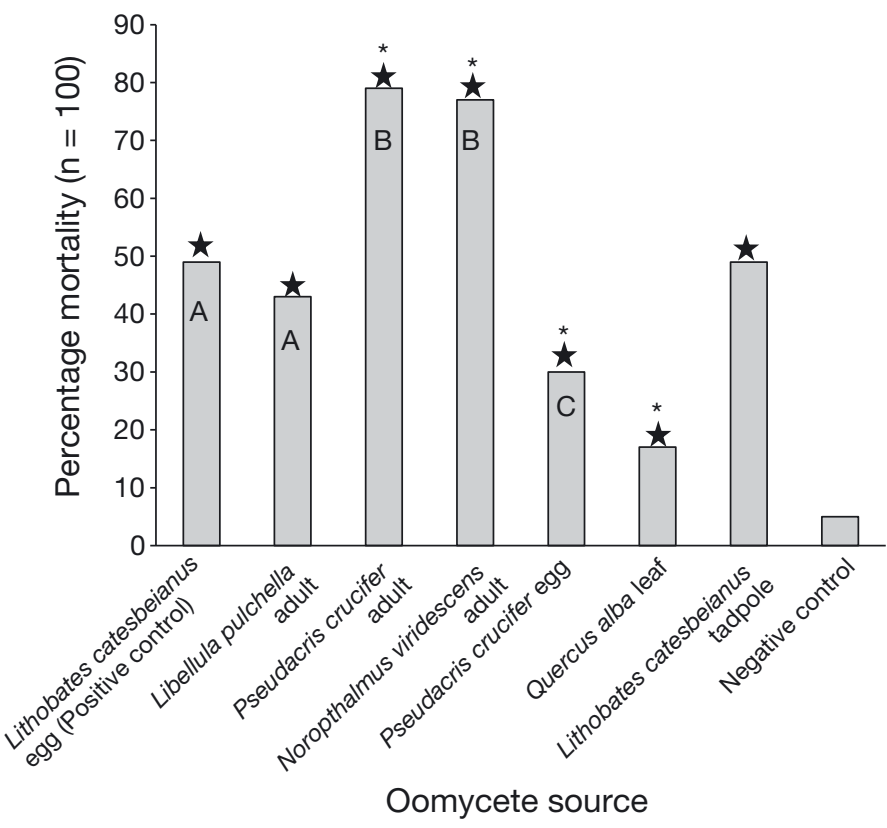

Fig. 2. Lithobates catesbeianus. Effect of water molds collected from the decaying bodies of organisms in Riopel Pond on bullfrog egg mortality. $(\star)$ significant difference from the sterile control $(\alpha=0.05)$. $(*)$ significant difference from 'Lithobates catesbeianus egg' isolate $(\alpha=0.05)$. Letters within bars are strain designations (Fig. 1). Strain A: Achlya sp., Strain B: Leptolegnia sp., Strain C: Saprolegnia sp. The Quercus alba leaf isolate was unique among our collections and is related to the genus Pythium. We were not able to identify the isolate collected from the L. catesbeianus tadpole. Strains A and B naturally colonized L. catesbeianus eggs in the field

organism, a dragonfly larva (Family Aeshnidae). The 'Quercus alba leaf' isolate had a unique sequence and, although pathogenic, was never found on a L. catesbeianus egg or any other organism in the field.

\section{DISCUSSION}

We isolated water molds from diverse substrates in Riopel Pond at MLBS, identified them by their ITS regions, and tested their ability to infect the eggs of Lithobates catesbeianus, a known host in our aquatic system. The water molds belonged to 5 genera; however most isolates clustered with members of the genus Leptolegnia (Fig. 1). Our isolates, which grew saprobically on several other species that share the same pond habitat, were also pathogenic to eggs of Lithobates catesbeianus. Aquatic oomycetes are common saprobes and pathogens in aquatic systems and the fact that the same strain can infect and colo- nize dead bodies of diverse species has important implications for the epidemiology of this multiple host, multiple pathogen system.

Our isolates differed significantly in their ability to infect Lithobates catesbeianus eggs and two were more infectious than isolates originally collected from a L. catesbeianus egg. All of the isolates caused significantly more mortality than the sterile control, indicating that some oomycetes have the potential to be pathogenic in nature. The infection test required the disruption of the jelly mass surrounding individual eggs. Because the jelly mass serves as one level of defense against infection (Gomez-Mestre et al. 2006), this disruption may have made the individual eggs more susceptible (Ruthig 2009). The wide range of dead eggs among the treatments and the very low mortality in our control, however, suggest that our manipulations of the jelly did not directly harm the embryos or make them susceptible to all microorganisms.

Water molds are saprobes in many aquatic systems (Johnson et al. 2002) and our samples were all isolated from dead organisms. This does not eliminate the possibility that some of the water molds we isolated killed their host organism. Pathogenicity tests on the other species from which we collected isolates would help determine whether these water molds caused their deaths. The infection test indicates that our oomycete strains may be capable of causing death of Lithobates catesbeianus eggs in nature. We did notice that $L$. catesbeianus embryos never became infected when they were more than $4 \mathrm{~d}$ old or after they hatched (see Ruthig 2009), suggesting that the strains that we used in this experiment were not pathogenic to L. catesbeianus tadpoles. We did, however, collect one of the strains in our experiment from a dead L. catesbeianus tadpole and oomycetes can infect tadpoles in other systems (Berger et al. 2001). Amphibian embryos can hatch and escape infection in other species of amphibians (Touchon et al. 2006), but the timing of hatching of L. catesbeianus eggs did not seem to change when neighboring eggs were infected (Ruthig 2006).

The variation in infection in our experiment was consistent among the proposed phylogenetic groupings. The 'Notopthalmus viridescens' and 'Pseudacris crucifer adult' isolates, both belonging to Strain B, were significantly more infectious than the positive control. The 'Libellula pulchella' and the 'Lithobates catesbeianus egg' isolates, both Strain A, did not differ significantly from each other in their ability to infect L. catesbeianus eggs. These examples support groupings under strains by ITS sequence and also 
suggest similar levels of pathogenicity by strain regardless of their source of isolation.

Although we found a diversity of water molds in our freshwater system, Strain A, a probable member of the genus Leptoplegnia, predominated. Most of the isolates collected over 3 consecutive years at MLBS grouped in Strain A. This strain also grew saprobically on several dead organisms in the system and was isolated repeatedly from Lithobates catesbeianus eggs. Strain B, probably belonging to the genus Achlya, was the next most common in the collection and also the most infectious. The genus Achlya has recently been documented infecting amphibian eggs in the Pacific Northwest (Ault et al. 2012). Strain C grouped with the genus Saprolegnia, which is a genus that has been commonly implicated in amphibian infections (Kiesecker et al. 2001, Gomez-Mestre et al. 2006, Fernández-Benéitez et al. 2008).

An important question is why the other strains that we tested in the infection experiment were not found on Lithobates catesbeianus eggs in the field. Several reasons could exist. (1) Water mold strains from other hosts may be less common and were not collected when we sampled L. catesbeianus eggs. (2) The water molds may be spatially separated from the $L$. catesbeianus eggs within the pond. The distribution of water molds within a pond is not uniform and species differ in where they reside within the water column (Johnson et al. 2002). (3) Our method of isolating water molds on cornmeal agar may have been selective for certain strains (Ault et al. 2012). (4) Finally, the environment may affect the ability of water molds to be pathogenic. The laboratory conditions under which we tested the ability of the water mold isolates to infect eggs may have improved the ability of some strains to infect the eggs but they may not have been able to do so in the field.

We found that dead organisms in a pond can contribute indirectly to the level of Lithobates catesbeianus egg mass infections. Similar indirect transmission of an oomycete to amphibian eggs has been reported before. Kiesecker et al. (2001) found that Saprolegnia strains that were pathogenic to eggs of the western toad Bufo boreas could come from soil contaminated with a Saprolegnia strain from an infected hatchery. Our results suggest that many species may act as reservoir hosts for oomycete strains that are pathogenic to L. catesbeianus eggs. The abundances and type of dead organisms in the environment may contribute to the natural occurrence of disease.

In host-pathogen systems where the pathogen can persist or amplify its numbers by acting as a saprobe, dead organisms should be considered as 'hosts' in the traditional host-pathogen sense. In aquatic systems where transmission is driven by motile propagules rather than direct contact, pathogens with multiple hosts can be modeled by incorporating an environmental reservoir that mediates transmission between and within species (Anderson \& May 1981: Model G). This host-pathogen framework may be applicable to many systems where the pathogen can infect multiple host species and can persist in the environment as a propagule, such as avian influenza (Rohani et al. 2009) and Haplosporidium nelsoni in oysters (Ford et al. 2009).

Traditional models of multihost pathogens focus on pairwise transmission parameters, or 'who acquires infection from whom' (WAIFW) (Anderson \& May 1984), to determine the rate of spread or basic reproductive rate, $R_{0}$, of a pathogen (Dobson 2004). WAIFW models require transmission parameters for each species pair, which can be difficult to measure in nature. They also do not accurately represent pathogens that are shed into the environment by infected hosts rather than infecting new hosts by direct contact. To incorporate additional host species to the Anderson \& May (1981) Model G, the population size of the environmental reservoir of infective propagules would be dependent on the sum of all of the host species in a community and the mortality rate of the propagules, rather than a single host population. Host species will likely differ in their susceptibility to colonization by propagules and the rate at which infected hosts contribute to the environmental pool of propagules.

Colonization rates and shedding rates of host species in multihost systems can be measured experimentally. Recent advances in quantitative PCR (e.g. Boyle et al. 2004 Kirshtein et al. 2007, Walker et al. 2007, Ruthig \& DeRidder 2012) have made detecting and counting microbes easier. Knowing colonization and shedding rates of potential host species in a community would allow researchers to estimate the risk of infection for focal host species.

We demonstrated that dead organisms that are colonized by facultative pathogens may serve as reservoir hosts. Saprobes that are facultative pathogens may drive the species on which they are pathogens to low numbers, but not decline themselves because of their ability to reproduce on dead hosts of multiple species. Estimating the transmission of pathogens within ecological communities is critical to understanding their role in linking communities and their ability to affect the population sizes of their hosts. 
Acknowledgements. This work was supported by the Mountain Lake Biological Station and the NSF/REU-Sites award DBI-0097249 to MLBS and by Grinnell College. H. Wilbur assisted developing the experimental design. M. Hood facilitated with the DNA extraction. Much of the molecular research was supported by Grinnell College. The manuscript benefited from helpful comments from J. Antonovics, V. Eckhart, K. Jacobson, X. Liu, S. Watanabe, A. Murray, and A. Hellmich.

\section{LITERATURE CITED}

Anaissie E (1992) Opportunistic mycoses in the immunocompromised host: experience at a cancer center and review. Clin Infect Dis 14:S43-S53

Anderson RM, May RM (1980) Infectious diseases and population cycles of forest insects. Science 210:658-661

Anderson RM, May RM (1981) The population dynamics of microparasites and their invertebrate hosts. Philos Trans R Soc Lond B 291:451-524

Anderson RM, May RM (1984) Spatial, temporal, and genetic heterogeneity in host populations and the design of immunization programmes. Math Med Biol 1:233-266

Ault KK, Johnson JE, Pinkart HC, Wagner RS (2012) Genetic comparison of water molds from embryos of amphibians Rana cascadae, Bufo boreas and Pseudacris regilla. Dis Aquat Org 99:127-137

Beakes GW, Burr AW, Wood SE, Hardham AR (1995) The application of spore surface features in defining taxonomic versus ecological groupings in oomycete fungi. Can J Bot 73:701-711

> Berger L, Speare R, Thomas A, Hyatt AD (2001) Mucocutaneous fungal disease in tadpoles of Bufo marinus in Australia. J Herpetol 35:330-333

> Blaustein AR, Hokit DG, O'Hara RK, Holt RA (1994) Pathogenic fungus contributes to amphibian losses in the Pacific Northwest. Biol Conserv 67:251-254

Boyle DG, Boyle DB, Olsen V, Morgan JAT, Hyatt AD (2004) Rapid quantitative detection of chytridiomycosis (Batrachochytrium dendrobatidis) in amphibian samples using real-time Taqman PCR assay. Dis Aquat Org 60:141-148

> Bradley DJ, Gilbert GS, Martiny JBH (2008) Pathogens promote plant diversity through a compensatory response. Ecol Lett 11:461-469

> Daniel CR III, Gupta AK, Daniel MP, Sullivan S (1998) Candida infection of the nail: role of Candida as a primary or secondary pathogen. Int J Dermatol 37:904-907

$>$ Daszak P, Cunningham AA, Hyatt AD (2000) Emerging infectious diseases of wildlife - threats to biodiversity and human health. Science 287:443-449

> Daszak P, Cunningham AA, Hyatt AD (2003) Infectious disease and amphibian population declines. Divers Distrib 9:141-150

> Dobson A (2004) Population dynamics of pathogens with multiple host species. Am Nat 164:S64-S78

Fenton A, Pedersen AB (2005) Community epidemiology framework for classifying disease threats. Emerg Infect Dis 11:1815-1821

> Fernández-Benéitez MJ, Ortiz-Santaliestra ME, Lizana M, Díeguez-Uribeondo J (2008) Saprolegnia diclina: another species responsible for the emergent disease 'Saprolegnia infections' in amphibians. FEMS Microbiol Lett 279:23-29

Ford SE, Allam B, Xu Z (2009) Using bivalves as particle collectors with PCR detection to investigate the environmental distribution of Haplosporidium nelsoni. Dis Aquat Org 83:159-168

> Gachon CMM, Strittmatter M, Müller DG, Kleinteich J, Küpper FC (2009) Detection of differential host susceptibility to the marine oomycete pathogen Eurychasma dicksonii by real-time PCR: not all algae are equal. Appl Environ Microbiol 75:322-328

> Godfray HCJ, Briggs CJ, Barlow ND, O'Calaghan M, Glare TR, Jackson TA (1999) A model of insect-pathogen dynamics in which a pathogenic bacterium can also reproduce saprophytically. Proc R Soc Lond B 266: 233-240

> Gomez-Mestre I, Touchon JC, Warkentin KM (2006) Amphibian embryo and parental defenses and a larval predator reduce egg mortality from water mold. Ecology 87: 2570-2581

> Harvey JBJ, Goff LJ (2006) A reassessment of species boundaries in Cystoseira and Halidrys (Phaeophyceae, Fucales) along the North American west coast. J Phycol 42:707-720

Hulvey JP, Padgett DE, Bailey JC (2007) Species boundaries within Saprolegnia (Saprolegniales, Oomycota) based on morphological and DNA sequence data. Mycologia 99: 421-429

Huxham M, Raffaelli D, Pike A (1995) Parasites and food web patterns. J Anim Ecol 64:168-176

Johnson TW Jr, Seymour RR, Padgett DE (2002) Biology and the systematics of the Saprolegniaceae. National Science Digital Library, University of North Carolina, Wilmington, NC. Available at http://dl.uncw.edu/digilib/biology/fungi/ taxonomy\%20and\%20systematics/padgett\%20book/

Karraker NE, Ruthig GR (2009) Effect of road deicing salt on the susceptibility of amphibian embryos to infection by water molds. Environ Res 109:40-45

Kidd SE, Hagen F, Tscharke RL, Huynh M and others (2004) A rare genotype of Cryptococcus gattii caused the cryptococcosis outbreak on Vancouver Island (British Columbia, Canada). Proc Natl Acad Sci USA 101:17258-17263

Kidd SE, Bach PJ, Hingston AO, Mak Sand others (2007) Cryptococcus gattii dispersal mechanisms, British Columbia, Canada. Emerg Infect Dis 13:51-57

Kiesecker JM, Blaustein AR, Miller CL (2001) Transfer of a pathogen from fish to amphibians. Conserv Biol 15: 1064-1070

Kirshtein JD, Anderson CW, Wood JS, Longcore JE, Voytek MA (2007) Quantitative PCR detection of Batrachochytrium dendrobatidis DNA from sediments and water. Dis Aquat Org 77:11-15

> Kuris AM, Hechinger RF, Shaw JC, Whitney KL and others (2008) Ecosystem energetic implications of parasite and free-living biomass in three estuaries. Nature 454: 515-518

Lafferty KD, Hechinger RF, Shaw JC, Whitney KL, Kuris AM (2006) Food webs and parasites in a salt marsh ecosystem. In: Collinge S, Ray C (eds) Disease ecology: community structure and pathogen dynamics. Oxford University Press, Oxford, p 119-134

- Leclerc MC, Guillot J, Deville M (2000) Taxonomic and phylogenetic analysis of Saprolegniaceae (Oomycetes) inferred from LSU rDNA and ITS sequence comparisons. Ant Leeuwenhoek 77:369-377

Martin WW (1981) Couchia circumplexa, a water mold parasitic in midge eggs. Mycologia 73:1143-1157 
Oidtmann B, Schaefers N, Cerenius L, Söderhäll K, Hoffmann R (2004) Detection of genomic DNA of the crayfish plague fungus Aphanomyces astaci (Oomycete) in clinical samples by PCR. Vet Microbiol 100:269-282

Papavizas GC, Ayers WA (1964) Effect of various carbon sources on growth and sexual reproduction of Aphanomyces euteiches. Mycologia 56:816-830

Petrisko JE, Pearl CA, Pilliod DS, Sheridan PP, Williams CF, Peterson CR, Bury RB (2008) Saprolegniaceae identified on amphibian eggs throughout the Pacific Northwest, USA, by internal transcribed spacer sequences and phylogenetic analysis. Mycologia 100:171-180

Phillips AJ, Anderson VL, Robertson EJ, Secombes CJ, van West P (2008) New insights into animal pathogenic oomycetes. Trends Microbiol 16:13-19

Pickering AD, Willoughby LG (1982) Saprolegnia infections of salmonid fish. In: Roberts RJ (ed) Microbial disease of fish. Proc 32nd Symp Soc General Microbiol. Academic Press, London, p 271-297

> Rohani P, Breban R, Stallknecht DE, Drake JM (2009) Environmental transmission of low pathogenicity avian influenza viruses and its implications for pathogen invasion. Proc Natl Acad Sci USA 106:10365-10369

Ruthig GR (2006) The influence of the environment and infectious disease on amphibian egg laying behavior. PhD thesis, University of Virginia, Charlottesville, VA

Ruthig GR (2008) The influence of temperature and spatial distribution on the susceptibility of southern leopard frog eggs to disease. Oecologia 156:895-903

Ruthig GR (2009) Water molds of the genera Saprolegnia and Leptolegnia are pathogenic to the North American

Editorial responsibility: Alex Hyatt,

Geelong, Victoria, Australia frogs Lithobates catesbeianus and Pseudacris crucifer, respectively. Dis Aquat Org 84:173-178

Ruthig GR, DeRidder BP (2012) Fast quantitative PCR, locked nucleic acid probes and reduced volume reactions are effective tools for detecting Batrachochytrium dendrobatidis DNA. Dis Aquat Org 97:249-253

> Tamura K, Dudley J, Nei M, Kumar S (2007) MEGA4: molecular evolutionary genetics analysis (MEGA) software version 4.0. Mol Biol Evol 24:1596-1599

> Touchon JC, Gomez-Mestre I, Warkentin KM (2006) Hatching plasticity in two temperate anurans: responses to a pathogen and predation cues. Can J Zool 84:556-563

Vilgalys R, Sun BL (1994) Ancient and recent patterns of geographic speciation in the oyster mushroom Pleurotus revealed by phylogenetic analysis of ribosomal DNA sequences. Proc Natl Acad Sci USA 91:4599-4603

- Walker SF, Salas MB, Jenkins D, Garner TW, Cunningham AA, Hyatt AD, Bosch J, Fisher MC (2007) Environmental detection of Batrachochytrium dendrobatidis in a temperate climate. Dis Aquat Org 77:105-112

White TJ, Bruns T, Lee S, Taylor J (1990) Amplification and direct sequencing of fungal ribosomal RNA genes for phylogenetics. In: Innis MA, Gelfand $\mathrm{DH}$, Sninsky JJ, White TJ (eds) PCR protocols: a guide to methods and applications. Academic Press, New York, NY, p 315-322

Williamson I, Bull CM (1994) Population ecology of the Australian frog Crinia signifera: egg-laying patterns and egg mortality. Wildl Res 21:621-631

Willoughby LG (1994) Fungi and fish diseases, 1st edn. Pisces Press, Stirling

Submitted: September 5, 2011; Accepted: August 1, 2012

Proofs received from author(s): October 2, 2012 